\title{
c-fos mRNA, Fos, and Fos-related Antigen Induction by Hypertonic Saline and Stress
}

\author{
Frank R. Sharp, Stephen M. Sagar, Katy Hicks, Daniel Lowenstein, and Kinya Hisanaga \\ Department of Neurology, University of California at Francisco and the San Francisco Veterans Affairs Medical Center, \\ San Francisco, California 94121
}

The induction of c-fos mRNA was assessed using Northern blots and in situ hybridization in adult rats administered hypertonic saline (HS) and isotonic saline (IS). HS induced c-fos mRNA in magnocellular paraventricular nucleus (PVNm), parvocellular paraventricular nucleus (PVNp), supraoptic nucleus (SON), and lamina terminalis (LMT). This occurred within $5 \mathrm{~min}$, peaked at 30-60 min, and disappeared by $180 \mathrm{~min}$. Fos protein, detected using a specific monoclonal antibody, was maximal at 1-2 $\mathrm{hr}$ and disappeared 4-8 hr after HS administration. This confirms observations showing that the c-fos gene response is transient even in the presence of a continuing stimulus.

In contrast, Fos-like immunoreactivity (FLI), detected using two polyclonal antisera, was observed in PVNm, PVNp, SON, and LMT for 1-24 hr during continuous osmotic stimulation. Moreover, FLI was observable in these structures for $7 \mathrm{~d}$ in rats administered HS and allowed to drink water ad libitum beginning $24 \mathrm{hr}$ later. At times greater than $8 \mathrm{hr}$, FLI presumably represents Fos-related antigens (FRA), proteins immunologically and functionally related to Fos, whose expression is much more prolonged than authentic Fos following the osmotic stimulus.

In addition to induction of c-fos expression in regions specifically involved in osmotic regulation, $\mathrm{HS}$ injections also induced $\mathrm{c}$-fos in many other forebrain regions. In order to assess the induction of c-fos mRNA due to the "stress" of the injections, rats injected with isotonic saline were compared to uninjected controls. Isotonic saline injections induced c-fos mRNA in the PVNp, anterior hypothalamus, suprachiasmatic nucleus, cingulate gyrus, neocortex, ventral lateral septal nucleus, piriform cortex, hippocampal pyramidal and dentate granule neurons, paraventricular and intralaminar thalamic nuclei, bed nuclei of stria terminalis, cortical and medial amygdaloid nuclei, and other structures. In accord with other work, we interpret this pattern of c-fos expression to result from the stress of handling and injections.

Since Fos and FRA probably bind to the promoters of target genes and regulate their expression, they likely mediate biochemical changes in the cells activated by the osmotic

\footnotetext{
Received Dec. 18, 1990; revised Mar, 5, 1991; accepted Mar. 12, 1991.

This work was supported by the research service of the Veterans Administration (F.R.S. and S.M.S.) and NIH Grants NS24666, NS28167 (F.R.S.), and NS27864 (S.M.S.). We thank Dr. Tom Curran and Dr. James Morgan (Roche) for providing a polyclonal antiserum to Fos and the c-fos riboprobe. Correspondence should be addressed to Dr. Sharp, Department of Neurology V127, Veterans Affairs Medical Center, 4150 Clement St., San Francisco, CA 94121.

Copyright (C) 1991 Society for Neuroscience $0270-6474 / 91 / 112321-11 \$ 03.00 / 0$
}

and stressful stimuli. Whereas the Fos signal is transient, FRA may act on target genes for the duration of the stimulus or longer.

Fos is the 380-amino-acid protein product of c-fos. Fos and Jun complex with DNA to regulate transcription from specific target genes (Curran and Morgan, 1987; Curran, 1988; Sonnenberg et al., 1989c). Antibodies to some peptides of Fos recognize both Fos and related proteins termed Fos-related antigens (FRA). FRA are also induced by a variety of extracellular stimuli and have antigenic, structural, and DNA-binding properties in common with Fos (Sonnenberg et al., 1989a,b). Fos and FRA are proposed to act as "third messengers" that link extracellular signals to long-term alternations in gene expression (Verma and Sassone-Corsi, 1987; Curran, 1988).

Since ions, neurotransmitters, and growth factors induce c-fos, it is not surprising that many stimuli, including seizures, cutaneous stimulation, and cortical injury, induce Fos and FRA in brain (Morgan and Curran, 1986; Morgan et al., 1987; Dragunow and Robertson, 1987, 1988; Hunt et al., 1987; White and Gall, 1987; Sagar et al., 1988; Bartel et al., 1989; Draisci and Iadarola, 1989; Sharp et al., 1989a-c; Sonnenberg et al., $1989 \mathrm{a}, \mathrm{b})$. Induction of the c-fos gene in brain is mediated by many receptors including neuronal NMDA and opiate receptors (Szekely et al., 1987, 1989; Cole et al., 1989; Menetrey et al., 1989; Sonnenberg et al., 1989a; Hisanaga et al., 1991) as well as glial EGF and FGF receptors (Arenander et al., 1989; Condorelli et al., 1989; Hisanaga et al., 1990).

Water deprivation also induces Fos and possibly FRA (Sagar et al., 1988) in brain regions known to respond electrophysiologically to osmotic stimuli (Kalimo, 1975; Brimble and Dyball, 1977; Swanson and Sawchenko, 1983). In this study, we administered hypertonic saline intraperitoneally in order to define the time course of Fos and Fra induction related to the onset and cessation of the osmotic stimulus.

\section{Materials and Methods}

Spraguc-Dawley rats $(250-350 \mathrm{gm})$ were injected intraperitoneally with $4 \mathrm{cc}$ of isotonic $(0.9 \%) \mathrm{NaCl}$ or $4 \mathrm{cc}$ of hypertonic $(1.35 \%) \mathrm{NaCl}$. Following isotonic saline (IS), three subjects were allowed to survive for 5 $\mathrm{min}$, two for $20 \mathrm{~min}$, and seven for $60 \mathrm{~min}$. Following hypertonic saline (HS), three subjects were allowed to survive for $5 \mathrm{~min}$, two for $15 \mathrm{~min}$, two for $30 \mathrm{~min}$, five for $60 \mathrm{~min}$, three for $120 \mathrm{~min}$, two for $180 \mathrm{~min}$, three for $240 \mathrm{~min}$, and three for $24 \mathrm{hr}$. Opiate analgesics were not administered following HS because these drugs affect Fos and FRA Subjects were anesthetized with ketamine $(80 \mathrm{mg} / \mathrm{kg}$, i.p.) and xylazine (20 $\mathrm{mg} / \mathrm{kg}$, i.p.) and perfused with $100 \mathrm{cc}$ of IS and heparin $(10 \mathrm{U} / \mathrm{cc})$ and $500 \mathrm{cc}$ of $4 \%$ paraformaldehyde (PFA) in $0.1 \mathrm{M}, \mathrm{pH} 7.4$, phosphate buffer. Six controls were anesthetized in the animal room without prior handling and perfused within $5 \mathrm{~min}$. Brains were removed and postfixed 


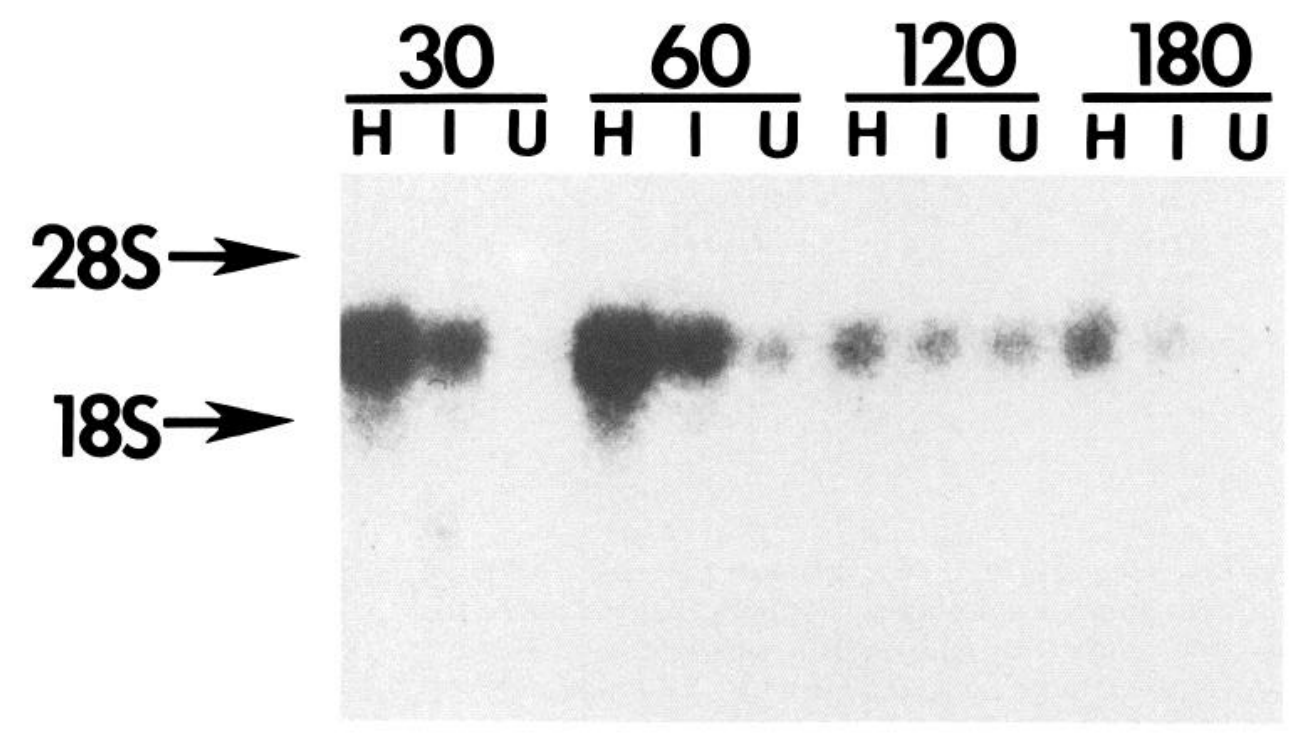

Figure 1. Northern blots of c-fos mRNA from adult rat hypothalamus of uninjected control subjects $(U)$, of subjects injected intraperitoneally with isotonic $(I)$ saline, and of subjects injected intraperitoneally with hypertonic $(H$ saline. The c-fos mRNA responses $(n=$ 3 for each blot) at $30,60,120$, and 180 min after saline injection are pictured.

overnight. 50 - or $100-\mu \mathrm{m}$-thick coronal sections were cut on a vibratome from the anterior commissure through the hypothalamus and placed in sterile tissue culture wells with DEP-treated phosphate buffer (PB).

Fos immunocytochemistry. Alternate sections were placed in $2 \%$ horse serum $/ 0.2 \%$ Triton X-100/0.1\% BSA (Hors) for $15 \mathrm{~min}$. Sections were incubated for $72 \mathrm{hr}$ at $+5^{\circ} \mathrm{C}$ on a slow shaker in primary antibody diluted 1:3000 in Hors. The antibody was a monoclonal raised to a synthetic peptide (Fos 4-17) from the N-terminal end of Fos (LA041; Microbiological Associates, Bethesda, MD). This peptide has little homology with known Fos-related antigens, and the antibody produces one band on Western blots (De Togni et al., 1988). Therefore, LA041 is presumed to be specific for Fos. Sections were immunostained as previously described (Sharp et al., 1990) using an Elite Vectastain kit (Burlingame, CA). Control sections, incubated in the presence of $2 \mu \mathrm{g} /$ $\mathrm{ml}$ of synthetic $\mathrm{N}$ peptide, showed no nuclear staining.

Immunohistochemistry with polyclonal antisera. Subjects were given HS intraperitoneally and divided into three groups. The first group was not allowed to drink water. Following survivals of 1, 2, 3, 4, and $24 \mathrm{hr}$ $(n=2$ at each time), they were anesthetized and perfused with PLP fixative ( $2 \%$ paraformaldehyde, $0.1 \mathrm{M}$ lysine, and $0.2 \%$ periodate in $\mathrm{PB}$ ). The second group began drinking water ad libitum $1 \mathrm{hr}$ after intraperitoneal HS. The third group began drinking water ad libitum $24 \mathrm{hr}$ after intraperitoneal HS. For the second and third groups, two subjects were anesthetized and perfused with PLP fixative 1, 2, 3, and $4 \mathrm{hr}$ and 1, 2, 3,4 , and $7 \mathrm{~d}$ after administration of the HS. Following perfusion, brains of subjects in all groups were removed, postfixed $1-4 \mathrm{hr}$ in PLP, and cut on a vibratome. Sections were immunostained for Fos and FRA using one of two polyclonal antibodies. One antibody to the M peptide (Fos 127-152) recognizes authentic Fos and two lower molecular weight FRA on Western blots (Sonnenberg et al., 1989a,b). The second polyclonal antibody, R1B6, was raised in our laboratory to the M2 peptide (Fos 132-154). It also recognizes Fos and two lower molecular weight FRA on Western blots (Aronin et al., 1990). The ABC immunocytochemical method was employed to visualize Fos and FRA as previously described (Sagar et al., 1988; Sharp et al., 1989a-c; Sagar and Sharp, 1990). Control sections incubated in the presence of the appropriate $M$ or M2 peptide $(1 \mu \mathrm{g} / \mathrm{ml})$ showed no staining. The relative amount of immunostaining using the monoclonal (see Table 1) and polyclonal antibodies (see Table 3 ) was scored as undetectable (0), trace (Tr), and up to maximal $(3+)$.

In situ hybridization. Free-floating sections in tissue culture wells were processed as previously described (Sharp et al., 1990). Hybridization was performed for $8 \mathrm{hr}$ at $65^{\circ} \mathrm{C}$ in $4 \times \mathrm{SSC}, 50 \%$ formamide, $1 \times$ Denhardt's reagent, $1 \mathrm{mg} / \mathrm{ml}$ salmon sperm DNA, $1 \mathrm{mg} / \mathrm{ml}$ yeast tRNA, $20 \mathrm{~mm}$ dithiothreitol, $5 \mathrm{~mm}$ EDTA, and $2.5 \times 10^{6} \mathrm{cpm} / \mathrm{ml}$ complementary ${ }^{35} \mathrm{~S}$-radiolabeled RNA probe shortened to an average length of about 150 bases by alkaline hydrolysis. The RNA probe was synthesized using a plasmid kindly provided by Dr. Curran (Roche, Nutley, NJ). The plasmid contains the full-length c-fos cDNA cloned into pSP65 in the antisense direction relative to the SP6 promoter. Once hybridized, washed, and treated with RNAase, sections were mounted onto gelatinized slides that were placed in $x$-ray film cassettes with Kodak SB5 film for $5 \mathrm{~d}$. Following this, the slides were dipped in Kodak NTB2 nuclear emulsion. After a 5-week exposure, they were developed in D19 for $3 \mathrm{~min}$, washed, fixed, washed, dried, and coverslipped. Control sections from selected subjects were hybridized with sense probe.

To quantify the hybridization signal, $\mathbf{x}$-ray film autoradiographs were digitized on a video camera/IBM computer-based image analysis system (MCID, Canada). The optical densities of areas of interest were measured on at least three sections from each subject. The average optical density for each region of each subject was divided by the average optical density of the internal capsule to obtain an optical density ratio (ODR) for each region. Significant differences between groups were determined using a Student's $t$ test $(p<0.05)$.

Northern blotting. Northern blots were performed from a separate group of subjects allowed to survive $30,60,120$, and $180 \min (n=3$ at each time) after each of the following manipulations. Subjects were administered either $4 \mathrm{cc}$ of IS intraperitoneally or $4 \mathrm{cc}$ of HS intraperitoneally or were left alone to serve as uninjected controls. Subjects were narcotized with $\mathrm{CO}_{2}$ and decapitated. The hypothalamus was dissected and frozen on dry ice. Total RNA was extracted in $5 \mathrm{~m}$ guanidinium isothiocyanate followed by precipitation in $3 \mathrm{M} \mathrm{LiCl}$. Following pro-

Table 1. Fos protein immunostaining obtained with the LA041 monoclonal antibody in PVNm neurons from three adult rats following intraperitoneal administration of $4 \mathrm{cc}$ of hypertonic (1.35\%) saline

Time (hr)

Immunostaining
Osmolarity

29$$
0
$$

1
$2+$

340

2
$3+$
338

338

3
$2+$
333

333

4
$1+$

328

$\begin{array}{rr}5 & 6 \\ 1 & \operatorname{Tr} \\ 326 & 325\end{array}$
less than $1 \mathrm{mmol} / \mathrm{kg}$ ). They did not have access to food or water for the duration of the experiment. The relative immunostaining in the PVNm was scored as undetectable (0), trace $(\mathrm{Tr})$, or up to maximal $(3+)$. 

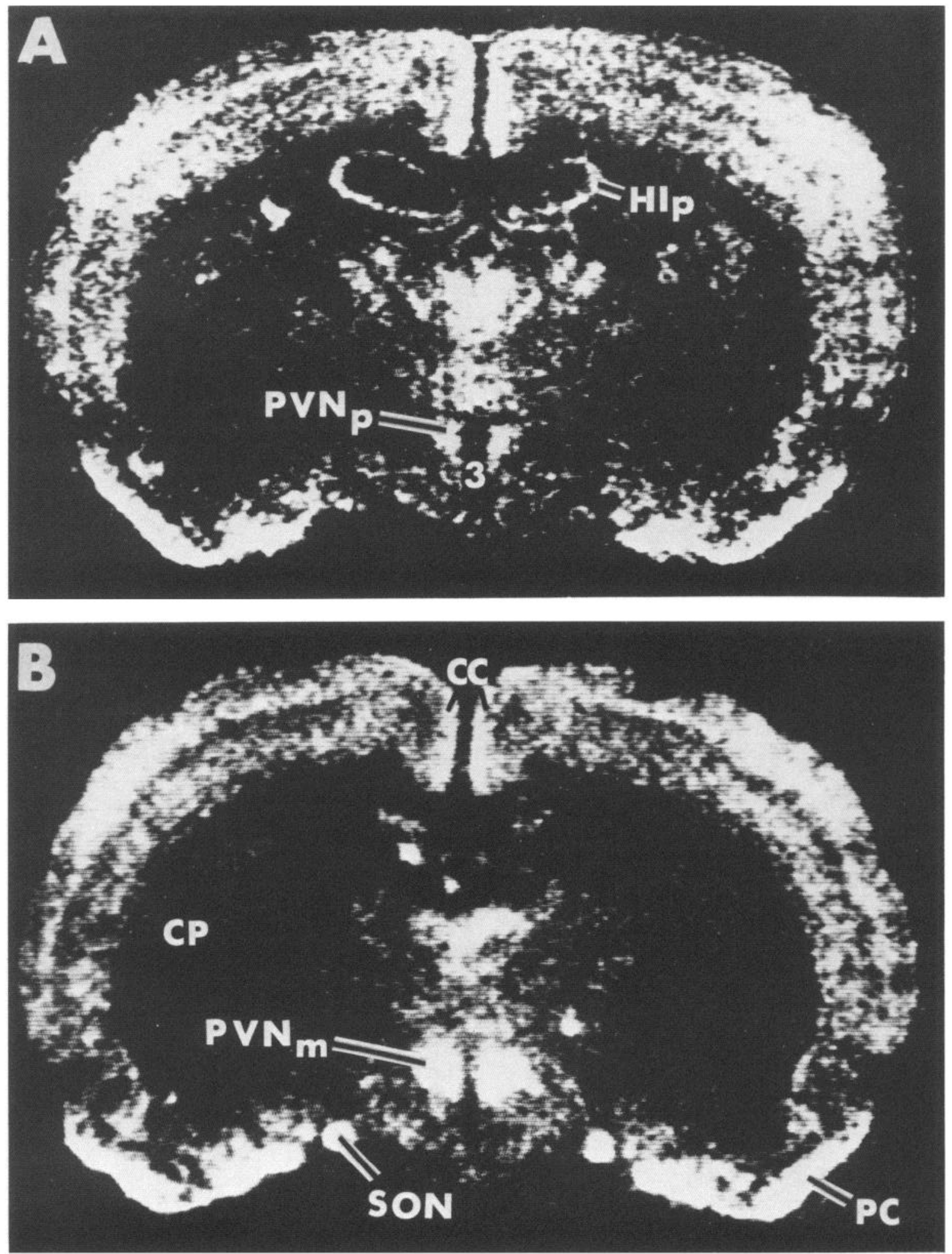

Figure 2. c-fos mRNA in situ hybridization coronal brain autoradiographs from subjects administered $(A)$ isotonic $(I S)$ saline and $(B)$ hypertonic $(H S)$ saline 60 min previously. $P V N m$, magnocellular paraventricular nucleus of hypothalamus; $P V N p$, parvocellular PVN; $S O N$, supraoptic nucleus; $H I p$, pyramidal neurons of hippocampus; $C C$, cingulate cortex; $P C$, piriform cortex; $C P$, caudate putamen; 3 , third ventricle.

teinase $\mathrm{K}$ digestion, phenol/chloroform extractions, and ethanol precipitation, RNA was quantified by OD at $260 \mathrm{~nm}$. Five micrograms of RNA was denatured in $50 \%$ formamide, loaded onto a $1.5 \%$ horizontal agarose gel, and electrophoresed in the presence of $2.2 \mathrm{M}$ formaldehyde.
The RNA was transferred to a nylon membrane filter (Nytran, Schleicher and Schuell) by capillary blotting and hybridized at high stringency [1.5 $\times$ saline/sodium/phosphate/EDTA (SSPE), $50 \%$ formamide at $\left.65^{\circ} \mathrm{C}\right]$ to the full-length complementary ${ }^{32} \mathrm{P}-\mathrm{RNA}$ probe. After washing at $65^{\circ} \mathrm{C}$ 


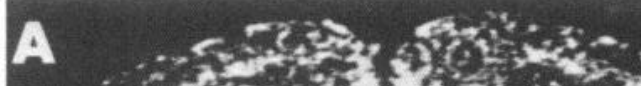

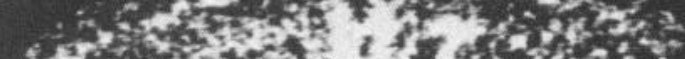

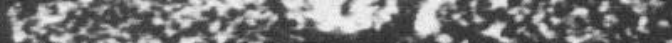

is

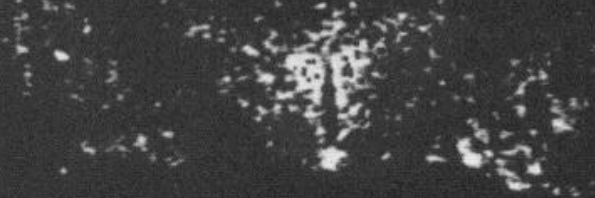
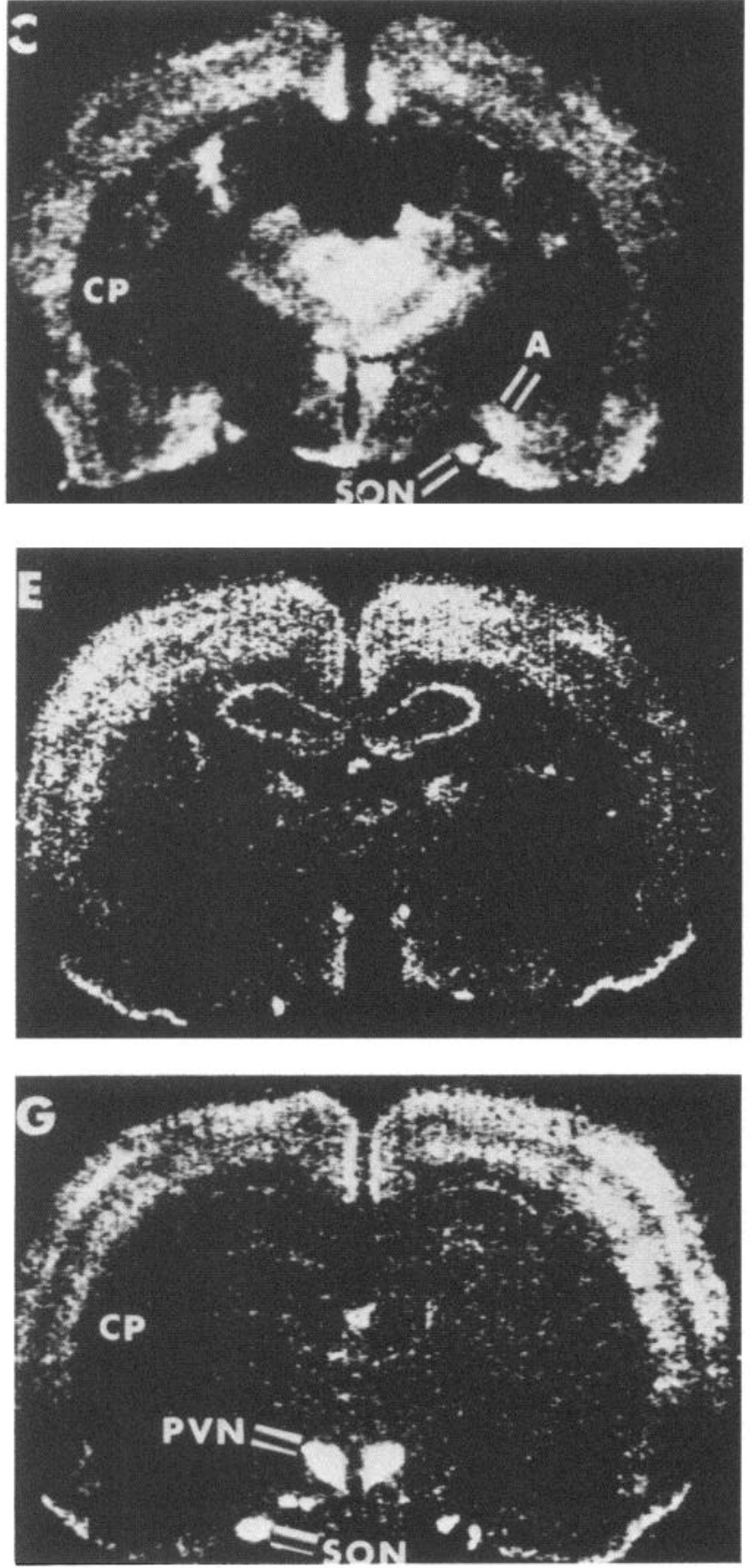
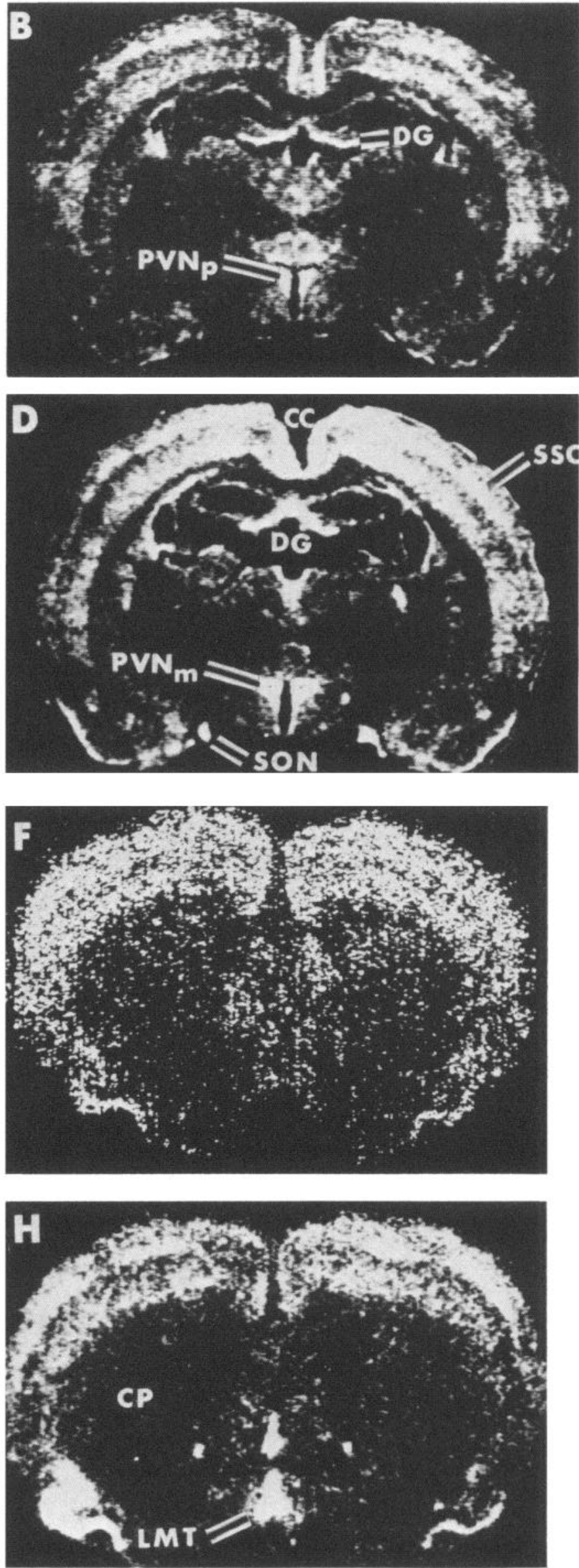
Table 2. Optimal density ratios obtained from c-fos $m R N A$ in situ hybridization autoradiographs of control subjects compared to subjects injected with isotonic (IS) and hypertonic (HS) saline

\begin{tabular}{llllll} 
Region & $\begin{array}{l}\text { Control } \\
(n=6)\end{array}$ & $\begin{array}{l}5 \mathrm{~min} \text { IS } \\
(n=3)\end{array}$ & $\begin{array}{l}20 \mathrm{~min} \text { IS } \\
(n=2)\end{array}$ & $\begin{array}{l}1 \mathrm{hr} \text { IS } \\
(n=7)\end{array}$ & $\begin{array}{l}1 \mathrm{hr} \text { HS } \\
(n=5)\end{array}$ \\
\hline LMT & $1.06 \pm 0.02$ & $1.25+0.06^{*}$ & $1.04+0.02$ & $1.06 \pm 0.09$ & $1.43 \pm 0.14^{*} !$ \\
PC & $1.18 \pm 0.21$ & $2.11 \pm 0.40^{*}$ & $1.38 \pm 0.07^{*}$ & $1.30 \pm 0.16^{*}$ & $1.34 \pm 0.25^{*}$ \\
CC & $1.14 \pm 0.06$ & $1.36 \pm 0.14^{*}$ & $1.25 \pm 0.02^{*}$ & $1.19 \pm 0.13$ & $1.22 \pm 0.11$ \\
LS & $1.08 \pm 0.05$ & $1.22 \pm 0.08^{*}$ & $1.14 \pm 0.09$ & $1.11 \pm 0.07$ & $1.10 \pm 0.07$ \\
SCN & $1.22 \pm 0.03$ & $1.34 \pm 0.06^{*}$ & $1.29 \pm 0.08$ & $1.29 \pm 0.11$ & $1.30 \pm 0.15$ \\
SSC & $1.18 \pm 0.13$ & $1.35 \pm 0.05^{*}$ & $1.31 \pm 0.03^{*}$ & $1.22 \pm 0.15$ & $1.27 \pm 0.15$ \\
PVA & $1.11 \pm 0.06$ & $1.33 \pm 0.05^{*}$ & $1.16 \pm 0.04$ & $1.17 \pm 0.08$ & $1.19 \pm 0.09$ \\
AN & $1.07 \pm 0.04$ & $1.19 \pm 0.04^{*}$ & $1.10 \pm 0.04$ & $1.08 \pm 0.06$ & $1.08 \pm 0.04$ \\
CP & $1.06 \pm 0.03$ & $1.10 \pm 0.02$ & $1.05 \pm 0.01$ & $1.06 \pm 0.04$ & $1.03 \pm 0.01$ \\
LH & $1.05 \pm 0.02$ & $1.11 \pm 0.03$ & $1.05 \pm 0.03$ & $1.05 \pm 0.02$ & $1.08 \pm 0.04$ \\
VL & $1.05 \pm 0.04$ & $1.09 \pm 0.02$ & $1.06 \pm 0.02$ & $1.05 \pm 0.04$ & $1.03 \pm 0.02$
\end{tabular}

Controls were not injected. Experimental subjects either were injected intraperitoneally with isotonic $(0.9 \%)$ saline (IS) and sacrificed at the indicated times or were injected with hypertonic (1.35\%) saline (HS) and sacrificed $1 \mathrm{hr}$ later. Optical densities (OD) of each structure were measured on x-ray films and divided by the OD of white matter to obtain OD ratios. The mean OD ratio \pm SD for each structure for the animals in each group is listed. Differences $(p<0.05)$ between saline-injected (IS and HS) and uninjected control animals $\left(^{*}\right)$ and between the 1-hr isotonic and hypertonic saline-treated animals (!) were evaluated using the Student's $t$ test.

for $1 \mathrm{hr}$ each with $2 \times \mathrm{SSC} / 0.1 \%$ SDS, $0.5 \times \mathrm{SSC} / 0.1 \%$ SDS, and 0.2 $\times \mathrm{SSC} / 0.1 \%$ SDS, the membrane was exposed overnight to Kodak XAR film with an intensifying screen at $-70^{\circ} \mathrm{C}$.

Plasma osmolarity. Four rats were anesthetized, and PE50 catheters were inserted into the femoral artery with minimal blood loss. After obtaining a 100- $\mu$ l blood sample, $4 \mathrm{cc}$ of HS was administered intraperitoneally. Blood samples $(100 \mu \mathrm{l})$ were then obtained each hour for the next $8 \mathrm{hr}$ and replaced with equal amounts of isotonic saline. The plasma osmolarities of these centrifuged blood samples were measured with a Wescor vapor pressure osmometer (Table 1).

Four additional rats were administered $4 \mathrm{cc}$ of HS intraperitoneally. Two were allowed to begin drinking water $1 \mathrm{hr}$ later, and two were allowed to begin drinking water $24 \mathrm{hr}$ later. At 1, 2, 3, and $7 \mathrm{~d}$ after HS, subjects were anesthetized, $100-\mu \mathrm{l}$ blood samples were obtained via cardiac puncture, and plasma osmolarities were measured (see Table 3).

\section{Results}

The plasma osmolarities of subjects administered intraperitoneal hypertonic saline and not allowed to drink were maximal at $1 \mathrm{hr}$ and slowly decreased over the next $8 \mathrm{hr}$ (Table 1). However, their plasma osmolarities were still quite elevated $8 \mathrm{hr}$ after administration of the hypertonic saline (Table 1).

Differences in c-fos mRNA induction were detected between the hypertonic and isotonic saline-injected subjects and between the isotonic saline-injected subjects and the uninjected (U) control subjects (Fig. 1). Northern blots demonstrated a single species of c-fos mRNA in the hypothalamus. Hypertonic $(\mathrm{H})$ and isotonic (I) saline induced c-fos mRNA in the hypothalamus compared to uninjected (U) controls at 30-180 min following saline administration (Fig. 1). However, injections of hypertonic saline induced c-fos mRNA to a greater extent (two- to threefold increases in optical density) than isotonic saline, the peak occurring 30-60 min following saline administration (Fig. 1).

In situ hybridization showed that more c-fos mRNA was induced in the magnocellular parvaventricular nucleus (PVNm), supraoptic nuclei (SON), and lamina terminalis (LMT) at 5 and $15 \mathrm{~min}$ following administration of hypertonic (Figs. $3 C ; 4$; $5 A, C$ ) compared to isotonic saline (Figs. $3 B, 4$ ). However, at 5 min the amount of $c_{-}$fos mRNA in the parvocellular PVN (PVNp) was similar in hypertonic and isotonic saline-injected subjects (Figs. $3 B, C ; 4 B$ ). At 30,60 , and $120 \mathrm{~min}$, more c-fos mRNA was induced in the PVNm, PVNp, SON, and LMT of the hypertonic (Figs. $2 B ; 3 D, G, H ; 4 ; 5 B, D, F$ ) compared to the isotonic (Figs. $2 A ; 3 E, F$ ) saline-injected subjects. At $180 \mathrm{~min}$, there was no difference in the amount of c-fos mRNA in hypertonic compared to isotonic saline-injected subjects in PVNII, PVNp, SON, and LMT (Fig. 4).

Immunocytochemistry using the LA041 monoclonal antibody revealed few if any Fos immunoreactive cells in PVNm, PVNp (Fig. 6A), SON (Fig. 7 $A$ ), and LMT (Fig. 6F) in uninjected controls and in subjects $5 \mathrm{~min}$ and $1 \mathrm{hr}$ after being injected with isotonic saline (Fig. $7 B$ ). Following administration of hypertonic saline, some Fos immunoreactivity was detected by $30 \mathrm{~min}$ (Fig. $6 B$ ), and substantial Fos was expressed in PVNm (Fig. 6C), PVNp (Fig. 6C), SON (Fig. 7D), and LMT (not pictured) by 1 hr. This response reached a maximum at $2 \mathrm{hr}$ (Figs. $6 D, G ; 7 E$ ) and disappeared by 4-8 hr. There was no immunostaining of PVNm, PVNp, SON, or LMT with the LA041 antibody at 8 (Table 1) or $24 \mathrm{hr}$ after administration of hypertonic saline.

Using the R1B6 polyclonal antiserum and the polyclonal antiserum developed by Curran (Sonnenberg et al., 1989a,b), there was heavy immunostaining of PVNm (Table 3), PVNp, SON, and LMT for 1-24 hr in subjects given hypertonic saline and not allowed to drink. In subjects allowed to drink $1 \mathrm{hr}$ after administration of hypertonic saline, R1B6 immunostaining was detectable in PVNm from 1 hr to $3 \mathrm{~d}$ later, but not at 4-7 d (Table 3). In subjects allowed to drink $24 \mathrm{hr}$ after administration of hypertonic saline, R1B6 immunostaining was detectable in

Figure 3. c-fos mRNA in situ hybridization coronal brain autoradiographs from an untouched control $(A)$, from subjects administered isotonic saline $5 \mathrm{~min}(B)$ and $30 \mathrm{~min}$ previously $(E$ and $F)$; and from subjects administered hypertonic saline $5 \mathrm{~min}(C)$ and 30 min previously $(D, G, H)$. $P V N p$, parvocellular PVN; $P V N$, paraventricular nucleus of hypothalamus; $S O N$, supraoptic nucleus; $L M T$, lamina terminalis; $C P$, caudate putamen; $A$, amygdala; $D G$, dentate gyrus; $S S C$, somatosensory cortex; $C C$, cingulate cortex. 

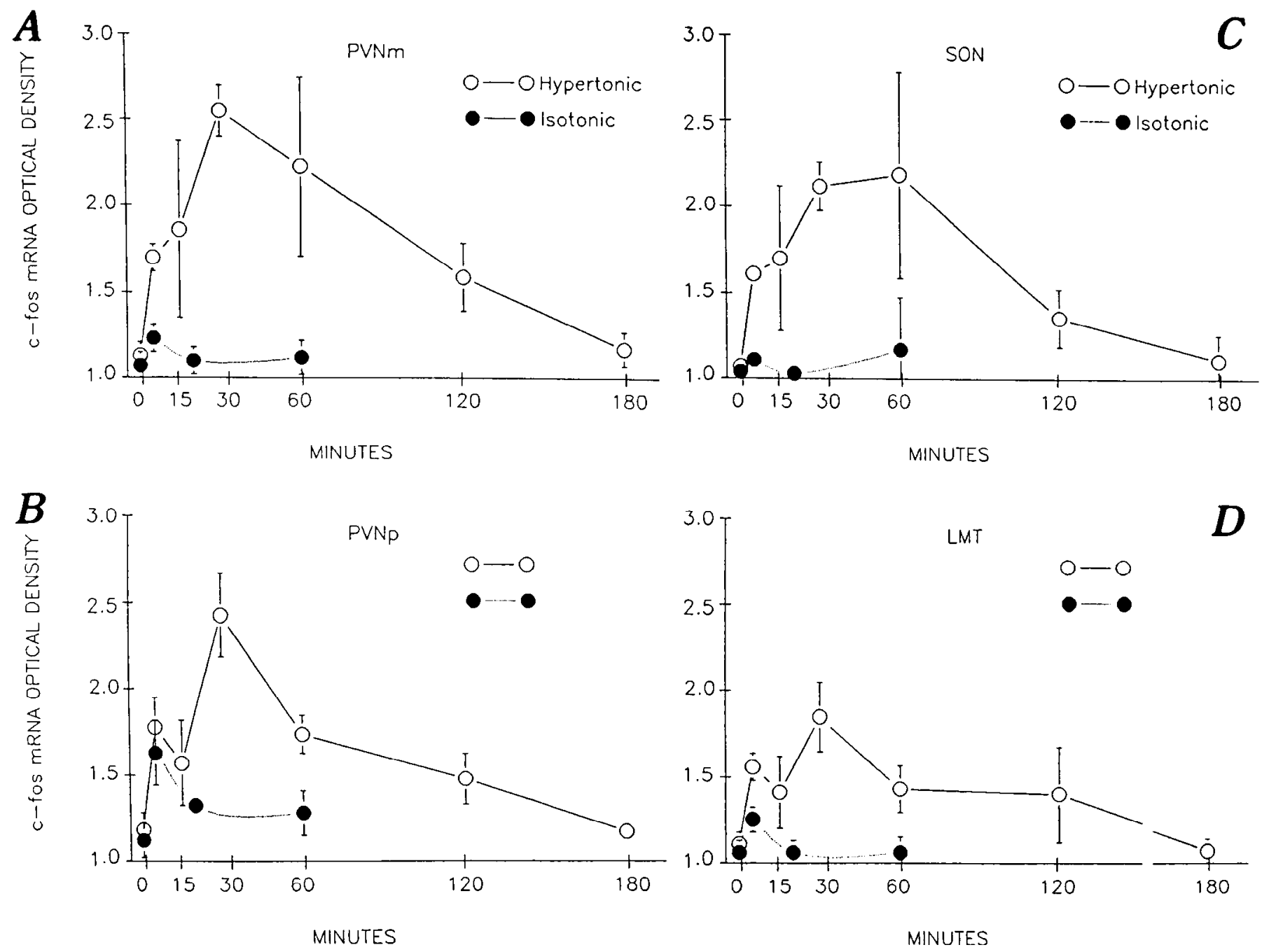

Figure 4. Expression of c-fos mRNA measured on x-ray film in situ hybridization autoradiographs for $(A)$ the magnocellular paraventricular nucleus of hypothalamus $(P V N m) ;(B)$ the parvocellular $(P V N p)$ paraventricular nucleus; $(C)$ the supraoptic nucleus $(S O N)$; and $(D)$ the lamina terminalis $(L M T)$ as a function of time after intraperitoneal administration of hypertonic (open circles) and isotonic (solid circles) saline.

the PVNm from $1 \mathrm{hr}$ to $7 \mathrm{~d}$ later (Table 3). Similar findings were observed in PVNp, SON, and LMT.

c-fos mRNA was induced in many structures of subjects injected with isotonic saline (Figs. $2 A ; 3 B, E, F$; Table 2) compared to uninjected controls (Fig. $3 A$, Table 2). These structures included the PVNp (Figs. $2 A, 3 B$ ), anterior hypothalamus (Fig. $3 B$ ), suprachiasmatic nucleus, cingulate cortex (Fig. $3 B$ ), neocortex (layers 2, 3, 5,6) (Figs. $2 A ; 3 B, E, F$ ), septal nucleus (Fig. $3 F$ ), olfactory/piriform cortex (Figs. $2 A ; 3 E, F$ ), the paraventricular and intralaminar thalamic nucleus, anterior thalamic nucleus (Fig. $3 B$ ), dentate gyrus granule neurons (Fig. $3 B$ ), hippocampal pyramidal neurons (Fig. $2 A$ ), bed nucleus of the stria terminalis, and the cortical and medial amygdaloid nuclei. We interpret this pattern as being due to the stress of handling and injection. The c-fos mRNA stress response peaked at 5-10 min after isotonic saline administration and disappeared by $1 \mathrm{hr}$ in all regions except piriform cortex (Table 2).

\section{Discussion}

Intraperitoneal hypertonic saline induced a transient c-fos mRNA response that peaked around $30-60 \mathrm{~min}$ and returned to baseline by 4-8 hr even though the osmotic stimulus continued for days. This is consistent with in vitro studies that show a transient c-fos mRNA response in spite of continued stimulation with growth factors, peptides, neurotransmitters, second messengcrs, and potassium depolarization (Kruijer et al., 1984; Curran and Morgan, 1985; Greenberg et al., 1986; Morgan and Curran, 1986; Sassone-Corsi et al., 1988; Areander et al., 1989; Bartel et al., 1989; Szekely et al., 1989). Moreover, other animal studies confirm a transient c-fos mRNA response following generalized seizures and other types of stimuli including hemorrhage (Morgan et al., 1987; Hoffman et al., 1989; Sonnenberg et al., 1989a,b).

Confusion about the duration of the Fos protein response has arisen because of the lack of specificity of antisera used. Foslike immunoreactivity (FLI) has been observed for 1-3 d following water deprivation (Sagar et al., 1988), trigeminal nerve section (Sharp et al., 1989c), cortical injury (Dragunow and Robertson, 1988; Sharp et al., 1989a), and adrenalectomy (Jacobson et al., 1990). However, since the antibodies used in these studies recognize both Fos and FRA, it is likely that the FLI represented both Fos and FRA.

LA041 is probably specific for authentic Fos, since it was 

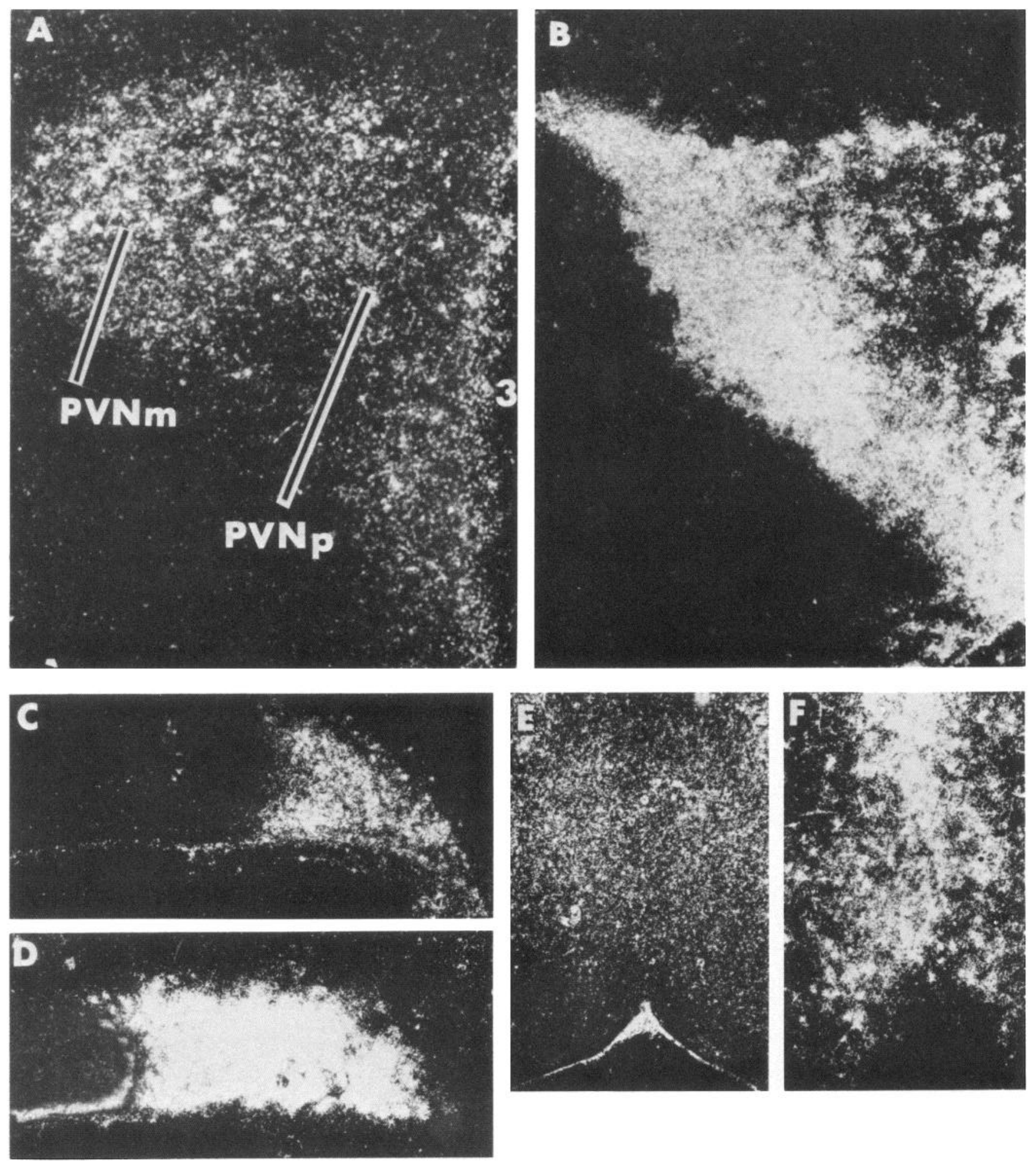

Figure 5. ${ }^{35} \mathrm{~S}$-labeled c-fos mRNA in the $P V N m$ and $P V N p$ of subjects administered hypertonic saline $15 \mathrm{~min}(A)$ and 60 min $(B)$ previously, in the SON of subjects administered hypertonic saline $15 \mathrm{~min}(C)$ and $60 \mathrm{~min}(D)$ previously, and in the LMT of subjects administered hypertonic saline $5 \mathrm{~min}(E)$ and $60 \mathrm{~min}(F)$ previously.

raised to a peptide on the $\mathrm{N}$-terminal end of Fos and it produces one band on Western blots (DeTogni et al., 1988). Using the LA041 monoclonal antibody, Fos disappears by 4-8 hr following cortical injury (Sharp et al., 1990) and osmotic stimuli (present study). These data suggest that the temporal expression of
Fos protein parallels the c-fos mRNA response. That is, the Fos protein is induced and disappears within 4-8 $\mathrm{hr}$ of the osmotic stimulation. This agrees with Sonnenberg et al. (1989a,b), who found that Fos protein is induced and disappears over a 4-5 hr period following administration of most convulsants. 

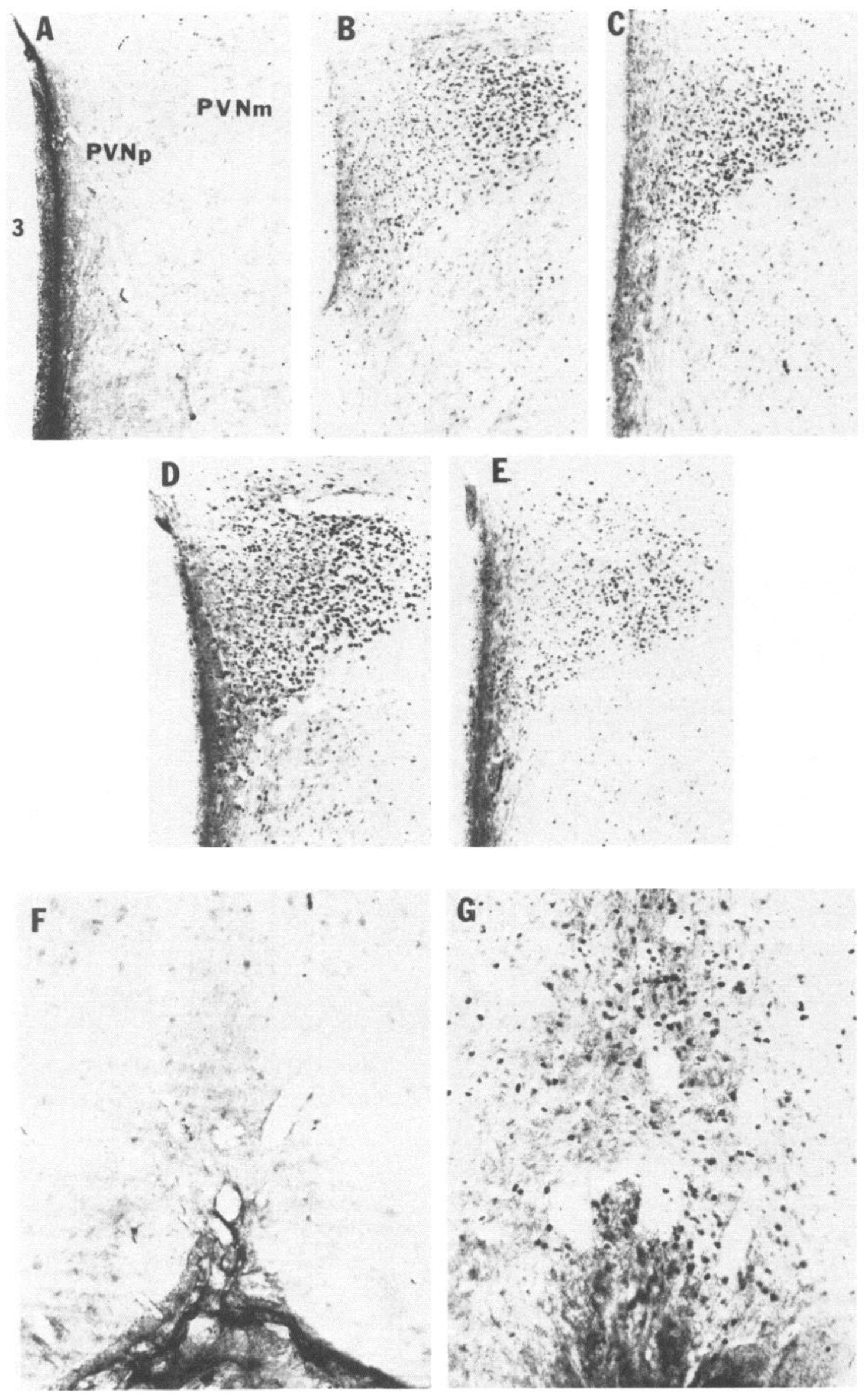

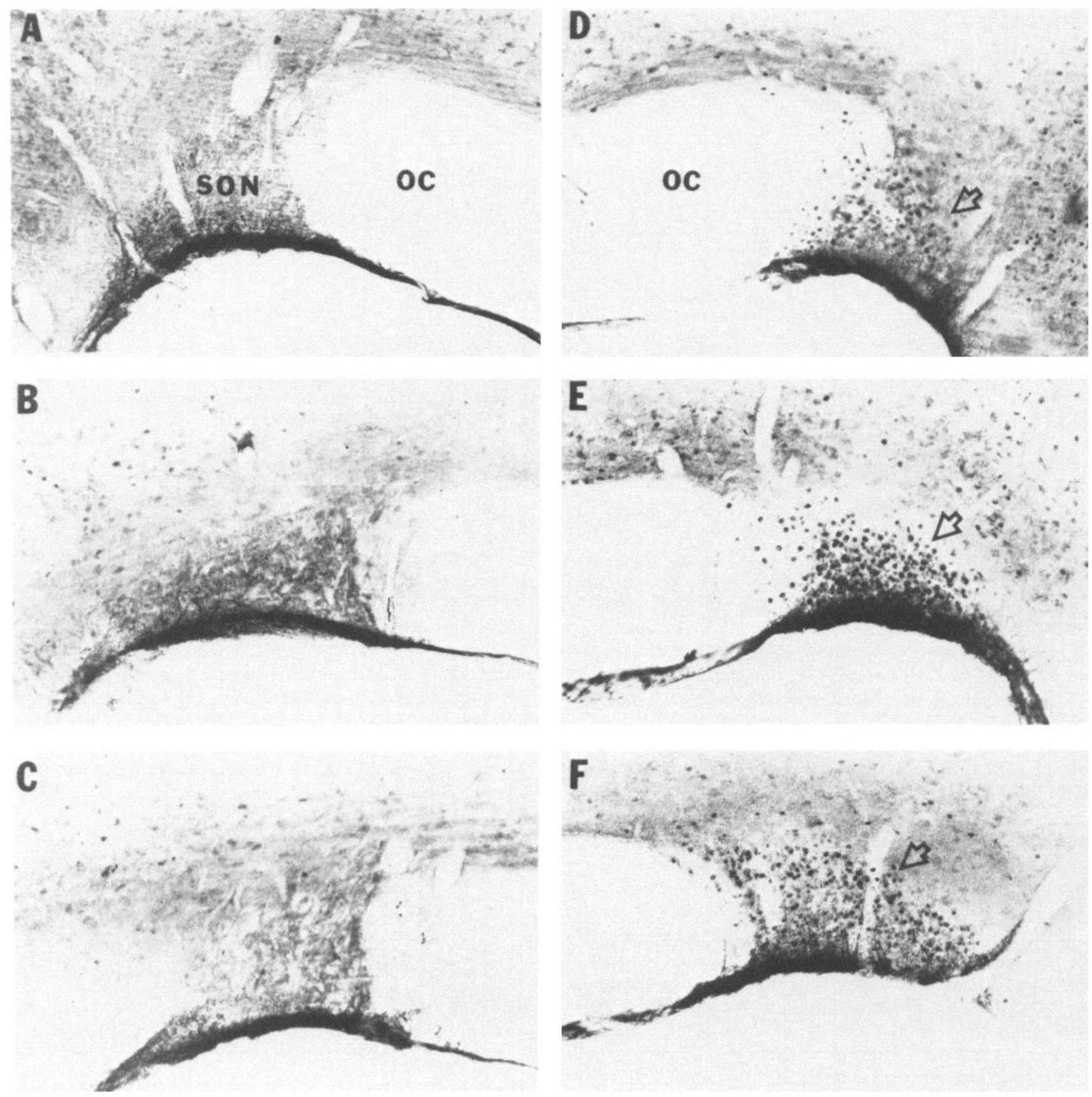

Figure 7. Coronal sections of the supraoptic nucleus $(S O N)$ stained immunocytochemically for Fos using the LA041 monoclonal antibody are pictured for an untouched control $(A), 1 \mathrm{hr}$ after administration of isotonic saline $(B)$, and $5 \mathrm{~min}(C), 1 \mathrm{hr}(D), 2 \mathrm{hr}(E)$, and $3 \mathrm{hr}(F)$ after administration of hypertonic saline.

Hypertonic saline induced FLI, detected using the R1B6 and Curran polyclonal antibodies, for up to $7 \mathrm{~d}$. Since hypertonic saline induced authentic Fos, detected using LA041, for only 4-8 $\mathrm{hr}$, the FLI present between $8 \mathrm{hr}$ and $7 \mathrm{~d}$ likely represented FRA. Similarly, Sonnenberg et al., (1989a,b) showed that, though
Fos disappears by $4 \mathrm{hr}$ following a seizure, 46- and 35-kDa FRA are expressed for at least $8 \mathrm{hr}$. Our observations suggest that Fos regulates transcriptional events related to the initial stimulus, since c-fos mRNA and Fos protein appear only transiently. FRA, however, continue to be expressed and regulate transcrip-

Figure 6. Coronal sections of the paraventricular nucleus stained immunocytochemically for Fos using the LA041 monoclonal antibody are pictured for an untouched control $(A)$ and for subjects administered hypertonic saline $30 \mathrm{~min}(B), 1 \mathrm{hr}(C), 2 \mathrm{hr}(D)$, and $3 \mathrm{hr}(E)$ previously. LA041 immunostaining in LMT $2 \mathrm{hr}$ following administration of hypertonic saline $(G)$ is also compared to LMT staining in an untouched control (F). 
Table 3. Polyclonal R1B6 immunostaining of PVNm neurons, representing FRA at times 1-7 d, and the plasma osmolarity $(\mathrm{mmol} / \mathrm{kg})$ in three groups of adult rats at various times following intraperitoneal administration of hypertonic saline

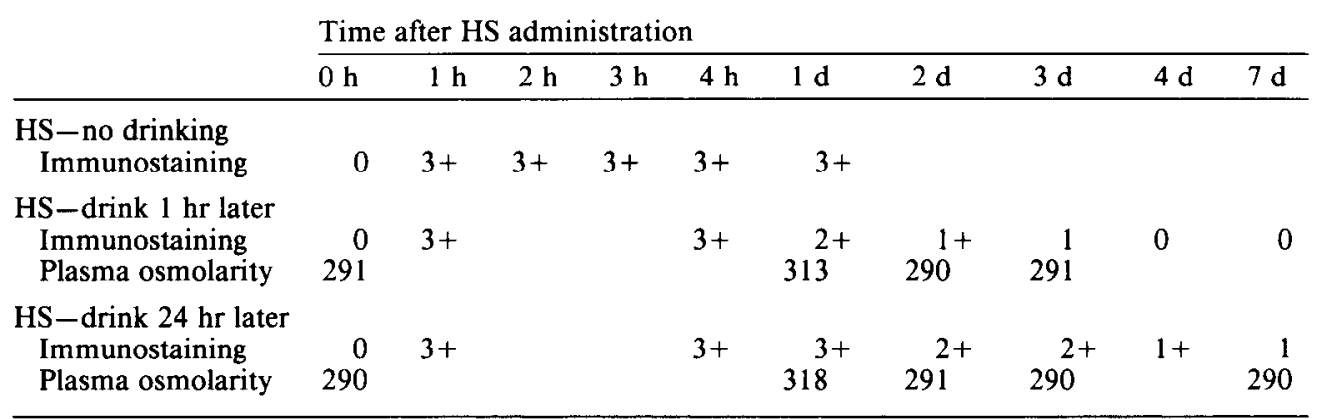

In the first group, the subjects were given hypertonic saline intraperitoneally and not allowed to drink water for $24 \mathrm{hr}$. In the second group, the subjects were allowed to begin drinking water ad libitum $1 \mathrm{hr}$ after intraperitoneal administration of the hypertonic saline. In the third group, the subjects were allowed to begin drinking water ad libitum $24 \mathrm{hr}$ after intraperitoneal administration of the hypertonic saline. The immunostaining was scored as undetectable $(0)$ to maximal $(3+)$.

tional events for long time periods that equal or exceed the duration of the stimulus.

Hypertonic saline produces both an osmotic and stress stimulus. To control for the latter, isotonic saline was given intraperitoneally since handling and the discomfort of injection should produce stress without an osmotic effect. Since hypertonic saline significantly increased c-fos mRNA in PVNm, PVNp, SON, and LMT at 30-120 min compared to isotonic injected subjects, we propose that the osmotic stimulus induced $c$-fos in those structures.

The PVNm, SON, LMT, and subfornical organ (SFO) are known to participate in osmotic regulation. SFO neurons, thought to be the primary transducers of osmotic stimuli in the brain (Johnson, 1985), increase their firing rate in response to hypertonic solutions and project to the LMT. Neurons in and near the LMT respond to the osmotic stimuli (Johnson, 1985). They are thought to be the integrative center for volume and osmotic information, to project to the magnocellular hypothalamic nuclei (Chaudhry et al., 1989; Tanaka, 1989), and to regulate oxytocin and vasopressin secretion. The magnocellular neurons of the PVN and SON contain oxytocin and vasopressin and send their axons into the posterior pituitary gland to secrete those hormones into the systemic circulation. The magnocellular neurons increase their firing rate in response to the systemic administration of hypertonic solutions (Brimble and Dyball, 1977). It is reasonable, therefore, that the osmotic stimulus induced the c-fos and fra immediate early genes in all of these regions. Whether or not osmotic and/or stressful stimuli induce Fos and FRA in SFO neurons is still under study.

Stress (or arousal) likely accounts for the induction of c-fos in subjects injected with isotonic saline compared to uninjected controls. Stress induces c-fos in cortex, amygdala, thalamus, hypothalamus, hippocampus, septum, PVNp, and other regions (Table 2). Stress (Ceccatelli et al., 1989) and adrenalectomy (Jacobson et al., 1990) have been shown to induce c-fos in corticotropin-releasing factor (CRF)-containing PVNp neurons. PVNp, however, appears to respond to both stress and osmotic stimulation (Fig. 6). PVNp has CRF-containing neurons that are activated during periods of stress, and it has neurons in which vasopressin is induced following osmotic simulation (Bondy et al., 1989). Further studies are needed to determine whether hormones and/or specific neural circuits mediate stress induction of $\mathrm{c}-f o s$ in PVNp and other brain regions.

The significance of the osmotic and stress induction of the c-fos and related genes is uncertain. The induction of c-fos could lead to long-term changes in expression of hormone and/or neurotransmitter genes (Sonnenberg et al., 1989c). Alternatively, Fos and FRA might regulate transcription from cytoskeletal gencs that produce the morphological changes in PVN and SON neurons induced by osmotic stimuli (Kalimo, 1975; Tweedle and Hatton, 1976). In any event, it is plausible that c-fos and other immediate early genes participate in the mechanism by which neurons make long-term biochemical adjustments to shortterm changes in neural activity.

\section{References}

Arenander AT, Lim RW, Varnum BC, Cole R, de Vellis J, Herschman HR (1989) TIS gene expression in cultured rat astrocytes: induction by mitogens and stellation agents. J Neurosci Res 23:247-256.

Aronin A, Sagar SM, Sharp FR, Schwartz WJ (1990) Light regulates expression of a Fos-related protein in rat suprachiasmatic nuclei. Proc Natl Acad Sci USA 87:5959-5962.

Bartel DP, Sheng M, Lau LF, Greenberg ME (1989) Growth factors and membrane depolarization activate distinct programs of early response gene expression: dissociation of fos and jun induction. Genes Dev 3:304-313.

Bondy CA, Whitnall MH, Brady LS, Gainer H (1989) Coexisting peptides in hypothalamic neurocndocrinc systcms: some functional implications. Cell Mol Neurobiol 9:427-446.

Brimble MJ, Dyball REJ (1977) Characterization of the responses of oxytocin- and vasopressin-secreting neurones in the supraoptic nucleus to osmotic stimulation. J Physiol (Lond) 271:253-271.

Ceccatelli S, Villar MJ, Goldstein M, Hokfelt T (1989) Expression of c-fos immunoreactivity in transmitter-characterized neurons after stress. Proc Natl Acad Sci USA 86:9569-9573.

Chaudhry MA, Dyball REJ, Honda K, Wright NC (1989) The role of interconnection between supraoptic nucleus and anterior third ventricular region in osmoregulation in the rat. J Physiol (Lond) 410: 123-135.

Cole AJ, Saffen DW, Baraban JM, Worley PF (1989) Rapid increase of an immediate early gene messenger RNA in hippocampal neurons by synaptic NMDA receptor activation. Nature 340:474-476.

Condorelli DF, Kaczmarek L, Nicoletti F, Arcidiacono A, Dell'Albani P, Ingrao F, Magri G, Malaguarnera L, Avola R, Messina A, Giuffrida S, Stella AM (1989) Induction of protooncogene fos by extracellular signals in primary glial cell cultures. J Neurosci Res 23:234-239. 
Curran T (1988) The fos oncogene. In: The oncogene handbook (Reddy EP, Skalka AM, Curran 'T, eds), pp 307-325. Amsterdam: Elsevier. Curran T, Morgan JI (1987) Memories of fos. Bioessays 7:255-258.

De Togni P, Niman H, Raymond V, Sawchenko P, Verma IM (1988) Detection of fos protein during osteogenesis by monoclonal antibodies. Mol Cell Biol 8:2251-2256.

Dragunow M, Robertson HA (1987) Kindling stimulation induces c-fos protein(s) in granule cells of the rat dentate gyrus. Nature 329: $441-442$.

Dragunow M, Robertson HA (1988) Brain injury induces c-fos protein(s) in nerve and glial-like cells in adult mammalian brain. Brain Res 455:295-299.

Draisci G, Iadarola MJ (1989) Temporal analysis of increases in c-fos, preprodynorphin and preproenkephalin mRNAs in rat spinal cord. Mol Brain Res 6:31-37.

Greenberg ME, Ziff EB, Greene LA (1986) Stimulation of neuronal acetylcholine receptors induces rapid gene transcription. Science 234: 80-83.

Hisanaga K, Sagar SM, Hicks KJ, Swanson RA, Sharp FR (1990) c-fos protooncogene expression in astrocytes associated with differentiation or proliferation but not depolarization. Mol Brain Res 8: $69-75$.

Hisanaga K, Sagar SM, Sharp FR (1991) $N$-methyl-d-aspartate antagonists block Fos-like protein expression induced via multiple signalling pathways in cultured neurons. $J$ Neurochem, in press.

Hoffman GE, Roberts MM, Verbalis JG, Robinson AG (1989) Expression of $\mathrm{c}-\int o s$ in magnocellular hypothalamic neurons: specificity for oxytocin and vasopressin. Neurosci Abstr 15:189.

Hunt SP, Pini A, Evan G (1987) Induction of c-fos-like protein in spinal cord neurons following sensory stimulation. Nature 328:632634.

Jacobson L, Sharp FR, Dallman MF (1990) Induction of Fos-like immunoreactivity in hypothalamic neurons after adrenalectomy in the rat. Endocrinology 126:1709-1719.

Johnson AK (1985) The periventricular anteroventricular third ventricle (AV3V): its relationship with the subfornical organ and neural systems involved in maintaining body fluid homeostasis. Brain Res Bull 15:595-601.

Kalimo H (1975) Ultrastructural studies on the hypothalamic neurosecretory neurons of the rat. III. Paraventricular and supraoptic neurons during lactation and dehydration. Cell Tissue Res 163:151168.

Kruijer W, Cooper JA, Hunter T, Verma IM (1984) Platelet-derived growth factor induces rapid but transient expression of the c-fos gene and protein. Nature 312:711-716.

Menetrey D, Gannon A, Levine JD, Basbaum AI (1989) Expression of c-fos protein in interneurons and projection neurons of the rat spinal cord in response to noxious somatic, articular, and visceral stimulation. J Comp Neurol 285:177-195.

Morgan JI, Curran T (1986) Role of ion flux in the control of c-fos expression. Nature 322:552-555.

Morgan JI, Cohen DR, Hempstead JL, Curran T (1987) Mapping patterns of $\mathrm{c}-f \circ s$ expression in the central nervous system after seizure. Science 237:192-196.
Sagar SM, Sharp FR (1990) Light induces a Fos-like nuclear antigen in retinal neurons. Mol Brain Res 7:17-21.

Sagar SM, Sharp FR, Curran T (1988) Expression of c-fos protein in brain: metabolic mapping at the cellular level. Science 240:13281331.

Sassone-Corsi P, Sisson JC, Verma IM (1988) Transcriptional autoregulation of the proto-oncogene fos. Nature 334:314-319.

Sharp FR, Gonzalez MF, Hisanaga K, Mobley WC, Sagar SM (1989a) Induction of Fos-like immunoreactivity in rat forebrain following cortical lesions and NGF injections. Neurosci Lett 100:117-122.

Sharp FR, Gonzalez MF, Sharp JW, Sagar SM (1989b) C-fos expression and 14C 2-deoxyglucose uptake in the caudal cerebellum of the rat during motor/sensory cortex stimulation. J Comp Neurol 284: $621-636$.

Sharp FR, Griffiths J, Gonzalez MF, Sagar SM (1989c) Trigeminal nerve section induces Fos-like immunoreactivity (FLI) in brainstem and decreases FLI in sensory cortex. Mol Brain Res 6:217-220.

Sharp JW, Sagar SM, Hisanaga K, Jasper P, Sharp FR (1990) The NMDA receptor mediates cortical induction of Fos and Fos-related antigens following cortical injury. Exp Neurol 109:323-332.

Sonnenberg JL, Mitchelmore C, Macgregor-Leon PF, Hempstead J, Morgan JI, Curran T (1989a) Glutamate receptor agonists increase the expression of Fos, Fra, and AP-1 DNA binding activity in the mammalian brain. J Neurosci Res 24:72-80.

Sonnenberg JL, Macgregor-Leon PF, Curran T, Morgan JI (1989b) Dynamic alterations occur in the levels and composition of transcription factor AP-1 complexes after seizure. Neuron 3:359-365.

Sonnenberg JL, Rauscher FJ III, Morgan JI, Curran T (1989c) Regulation of proenkephalin by Fos and Jun. Science 246:1622-1625.

Swanson LW, Sawchenko PE (1983) Hypothalamic integration: organization of the paraventricular and supraoptic nuclei. Annu Rev Neurosci 6:269-324.

Szekely AM, Barbaccia ML, Costa E (1987) Activation of specific glutamate receptor subtypes increases c-fos proto-oncogene expression in primary cultures of cerebellar granule cells. Neuropharmacology 26:1779-1782.

Szekely AM, Barbaccia ML, Alho H, Costa E (1989) In primary cultures of cerebellar granule cells the activation of $N$-methyl- $d$-aspartate-sensitive glutamate receptors induces c-fos mRNA expression. Mol Pharmacol 35:401-408.

Tanaka J (1989) Involvement of the median preoptic nucleus in the regulation of paraventricular vasopressin neurons by the subfornical organ in the rat. Exp Brain Res 76:47-54.

Tweedle CD, Hatton GI (1976) Ultrastructural comparisons of neurons of supraoptic and circularis nuclei in normal and dehydrated rats. Brain Res Bull 1:103-121.

Verma IM, Sassone-Corsi P (1987) Proto-oncogene fos: complex but versatile regulation. Cell 51:513-514.

White JD, Gall CM (1987) Differential regulation of neuropeptide and proto-oncogene mRNA content in hippocampus following recurrent seizure. Mol Brain Res 3:21-29. 